\title{
C2 wt Allele
}

National Cancer Institute

\section{Source}

National Cancer Institute. C2 wt Allele. NCI Thesaurus. Code C126957.

Human C2 wild-type allele is located in the vicinity of $6 \mathrm{p} 21.3$ and is approximately $48 \mathrm{~kb}$ in length. This allele, which encodes complement C2 protein, plays a role in proteolysis and complement activation. Mutation of the gene is associated with C2 deficiency and increased susceptibility for age-related macular degeneration. 